\title{
Aplikasi Sistem SMS Hitung Cepat Berbasis PHP dan MYSQL (Studi Kasus Suara Gerindra Dapil 1 Pada Pemilu Legislatif 2014)
}

\author{
Agus Subkhi Hermawan ${ }^{1)}$, Oky Dwi Nurhayati ${ }^{2)}$, Ike Pertiwi Windasari \\ Program Studi Sistem Komputer, Fakultas Teknik, Universitas Diponegoro \\ Jl. Prof.Sudharto, Tembalang, Semarang, Indonesia \\ Email: hermawan.semangat@gmail.com
}

\begin{abstract}
General Election is the Indonesian greatest democracy party, which becomes an opportunity to the legislative candidates to compete. The success of the General Election is determined by the smooth running of the vote and the vote counting process. The process of organizing elections often encountered various problems, the fraud of several elements which inflate the votes in the polling stations, and corruption of the top elements' functionary. In order to avoid those problems, a hitung cepat is needed to inform the prediction of the election result faster than the official counting by the Commission of General Election. A hitung cepat can also be the proof of the election fraud. In this case, a hitung cepat application becomes one of the solutions to finish the vote counting faster than if manual counting is used. This application will help the official supporting teams in predicting their supported legislative candidates' winning.

This application is created by using several phases; they are system designing, prototype making, implementation, and program testing. All this phases are called prototyping method. This method is appropriatefor this project because it has a fast flow to fulfill the official supporting teams need in a dynamic political condition. The application designing is modeled by the UML.

This application is created by using PHP programming language to run the program itself, and supported by Gammu and $M y S Q L$ to run the function of the SMS gateway. In implementation phase, the quick count application can be used to count the vote of the legistative election in 2014 General Election by using statistic method. The level of accuracy used in this study was $99 \%$ with a margin of error $1 \%$.
\end{abstract}

Keywords-General Election, hitung cepat, application, legislative candidate

\section{PENDAHULUAN}

Reformasi 1998 telah membawa dampak yang sangat signifikan bagi perkembangan kebebasan politik di Indonesia. Kebebasan berpendapat, dipilih dan memilih semakin mewarnai politik nasional, terbukti dengan munculnya beragam calon legislatif (Caleg) dari berbagai partai yang dapat menjadi opsi pilihan masyarakat. Pemilihan Umum (Pemilu) adalah pesta demokratis yang ada di Indonesia, pemilu juga menjadi ajang bagi para caleg berkompetisi.

Keberhasilan pemilu ditentukan oleh kelancaran pengambilan suara dan proses perhitungan hasil suara. Namun dalam penyelenggaran pemilu sering ditemui berbagai masalah, salah satunya adalah lambatnya perhitungan suara. Hal ini dikarenakan suara hasil pemungutan di tempat pemungutan suara (TPS) dikumpulkan terlebih dahulu sebelum dihitung secara total.

Metode perhitungan yang dilakukan Komisi Pemilihan Umum (KPU) tersebut memiliki kelemahan yaitu lamanya waktu perhitungan suara. Padahal banyak pihak yang membutuhkan informasi yang cepat terkait hasil pemilu. Selain itu, metode ini menjadi salah satu cara oknum tertentu untuk melakukan kecurangan dengan menggelembungkan suara di TPS dan juga rawan terjadi korupsi di level atas. Untuk menghindari hal tersebut, maka diperlukan hitung cepat guna mengetahui prediksi hasil pemilu lebih cepat dari pada perhitungan resmi yang dilakukan oleh KPU dan menjadi bukti ketika terjadinya kasus kecurangan.

Pada Pemilu 2014, banyak lembaga yang melakukan Hitung cepat seperti Exitpoll, LSI, CSIS, dan CYRUS NETWORK. Tetapi setiap lembaga survei memberikan hasil yang berbeda-beda, dikarenakan jumlah sample dan metode survei berbeda, sehingga hal ini menimbulkan miss of real data. Untuk lebih nyakin dengan hasil hitung cepat maka banyak tim sukses dari Caleg melakukan perhitungan suara pada TPS sumber suara.

Seiring dengan pesatnya perkembangan teknologi khususnya dalam hal bidang teknologi informasi yang terdiri dari perkembangan perangkat lunak dan perangkat keras, maka dalam penelitian ini akan menghasilkan suatu aplikasi sistem SMS hitung cepat yang dapat menunjang pengumpulan data.

Untuk memfokuskan kajian dalam analisis, penulis membatasi ruang lingkup deskripsi pada pembuatan aplikasi sistem SMS hitung cepat menggunakan bahasa pemograman PHP, dan basis data yang digunakan MySQL dan tidak membahas bagaimana suasana politik pemilu, dan cara data phonebook didapatkan.

\section{LANDASAN TEORI}

\section{A. Hitung Cepat}

Menurut Ardiyanti (2013), hitung cepat adalah perhitungan secara cepat hasil pemilihan umum atau pemilihan kepala daerah dengan menggunakan TPS sampel. Dengan hitung cepat, hasil perhitungan suara bisa diketahui dua sampai tiga jam setelah perhitungan suara di TPS ditutup. 
Keabsahan hitung cepat telah diakui secara luas di dunia, dan sampai saat ini merupakan metode yang canggih dalam menentukan perkiraan siapa pemenang dari suatu pemilu, tanpa harus menghitung semua suara yang masuk (Kasman, 2014).

\section{B. Metode Pengembangan Perangkat Lunak dengan Siklus Hidup Pengembangan Perangkat Lunak}

Pada rekayasa perangkat lunak, banyak model yang telah dikembangkan untuk membantu proses pengembangan perangkat lunak. Model-model ini pada umumnya mengacu pada model siklus hidup pengembangan perangkat lunak atau sering disebut juga Software Development Life Cycle (SDLC). SDLC adalah proses mengembangkan atau mengubah suatu sistem perangkat lunak dengan menggunakan model-model dan metodologi yang digunakan orang untuk mengembangkan sistem-sistem perangkat lunak sebelumnya yang terdiri dari beberapa tahapan (Rosa dan Shalahuddin, 2013). Tahapantahapan tersebut diantaranya requirements (analisis kebutuhan), analysis (analisis sistem), design (perancangan), coding / implementation (implementasi), testing (pengujian) dan maintenance (perawatan). Dalam SDLC terdapat banyak model yang dapat dipakai untuk mengembangkan sebuah perangkat lunak, misal Prototyping, Waterfall, dan sebagainya.

1) Model Prototype: Model prototype dapat digunakan untuk menyambungkan ketidakpahaman pengguna mengenai hal teknis dan memperjelas spesifikasi kebutuhan yang diinginkan pengguna kepada pengembang perangkat lunak (Rosa dan Shalahuddin, 2011). Model prototype juga memiliki kelemahan sebagai berikut :

a. Pengguna dapat sering mengubah-ubah atau menambah-tambah spesifikasi kebutuhan karena menganggap aplikasi sudah dengan cepat dikembangkan, karena adanya iterasi ini dapat menyebabkan pengembang banyak mengalah dengan pengguna.

b. Pengembang lebih sering mengambil kompromi dengan pengguna untuk mendapatkan prototype dengan waktu yang cepat sehingga pengembang lebih sering melakukan segala cara (tanpa idealis) guna menghasilkan prototype untuk didemonstrasikan.

\section{Pemodelan Proses dalam Pengembangan Aplikasi}

Pemodelan proses adalah cara formal untuk menggambarkan bagaimana bisnis beroperasi. Mengilustrasikan aktivitas - aktivitas yang dilakukan dan bagaimana data berpindah di antara aktivitas-aktivitas itu (Hanif, 2007).

1) Data Flow Diagram: Merupakan representasi secara grafis dari aliran data yang melalui aplikasi, yang menggambarkan data seperti apa yang dimasukkan dan menjadi keluaran dari sistem, dari mana arah data dan kemana perginya, dan dimana data disimpan (Rosa dan Shalahuddin, 2013).

2) Kamus Data: Kamus data adalah kumpulan daftar elemen data yang mengalir pada sistem perangkat lunak sehingga masukan (input) dan keluaran (output) dapat dipahami secara umum (memiliki standar cara penulisan) (Rosa dan Shalahuddin, 2013).

3) Entity Relationship Diagram: Sebuah model data yang menggunakan beberapa notasi untuk menggambarkan data dalam hal entitas dan relasi yang digambarkan oleh data tersebut (Wahyono, 2009).

\section{Bahasa Pemograman Web}

Saat ini bahasa pemrograman web banyak sekali di antaranya adalah PHP, CSS, Javascript, dan lain sebagainya.

1) PHP: PHP (Preprocesor Hypertext) adalah bahasa berbentuk skrip yang ditempatkan pada server dan diproses di server. Hasilnya kemudian dikirimkan ke browser klien (Hirin dan Virgi, 2011).

2) Javascript: Javascript adalah bahasa yang berbentuk kumpulan skrip yang pada fungsinya berhalan pada suatu dokumen HTML. Sepanjang sejarah internet bahasa ini adalah bahasa skrip pertama untuk web. Bahasa ini adalah bahasa pemrograman untuk memberikan kemampuan tambahan terhadap HTML dengan mengijinkan pengeksekusian perintah-perintah di sisi klien, yang artinya di sisi browser bukan di sisi server (Adi dan Sanjay, 2012).

3) CSS: CSS yang merupakan singkatan dari Cascading Style Sheets, merupakan bahasa yang digunakan untuk menggambarkan semantik presentasi (tampilan dan format) dari dokumen yang dituliskan dengan menggunakan markup language atau dengan kata lain, CSS digunakan untuk memberikan gaya tampilan pada sebuah halaman web yang dituliskan dengan menggunakan bahasa HTML atau XHTML. Tetapi bahasa ini juga bisa diaplikasikan pada setiap jenis dokumen XML (Huda, dkk, 2010).

\section{E. Basis Data}

Sistem Basis Data adalah suatu sistem penyusunan dan pengelolaan record-record dengan menggunakan komputer, dengan tujuan untuk menyimpan atau merekam serta memelihara data operasional lengkap sebuah organisasi/perusahaan, sehingga mampu menyediakan informasi yang optimal yang diperlukan pemakai untuk kepentingan proses pengambilan keputusan (Solichin, 2011).

1) MySQL: MySQL adalah sebuah perangkat lunak sistem manajemen basis data SQL atau DBMS yang multithread, multi-user dengan sekitar 6 juta instalasi di seluruh dunia. MySQL AB membuat MySQL tersedia sebagai perangkat lunak gratis di bawah lisensi GNU General Public Licence (GPL). Tetapi mereka juga menjual di bawah lisensi komersial untuk kasus-kasus di mana penggunaannya tida cocok dengan pengunaan GPL (Santoso, dkk, 2006).

\section{F. Teknik Pengumpulan Data}

Teknik pengumpulan data dalam penelitian ada yang menggunakan teknik penelitian lapangan (field research), yaitu dengan cara mengumpulkan data-data dan informasi secara langsung pada lokasi dan objek penelitian (Rosa dan Shalahuddin, 2013). Ada beberapa teknik pengumpulan data yang sering dilakukan antara lain.

1) Teknik Wawancara: Teknik wawanacara digunakan untuk mendapatkan data kualitatif serta beberapa keterangan yang tidak diperoleh dari data sekunder. Wawancara mendalam ini dilakukan terhadap narasumber (key informan) yang dianggap memiliki pengetahuan yang memadai tentang suatu persoalan atau fenomena yang sedang diamati.

2) Teknik Observasi: Pengamatan langsung terhadap objek penelitian untuk menggali aspek-aspek yang relevan dan 
penting sebagai dasar analisis dan interpretasi yang akan dilakukan. Pengamatan di lapangan ini bertujuan untuk menggali kemungkinan adanya informasi yang terlewatkan dari pedoman wawancara yang dilakukan dan berupaya memperkaya dimensi pengamatan dari fenomena penelitian yang ada.

\section{G. Penentuan Sampel TPS Hitung cepat}

Berkaitan dengan penentuan jumlah sampel pemilih, maka perlu mempertimbangkan keragaman pemilih di Indonesia dan pertimbangan biaya yang dipakai untuk melakukan hitung cepat. Berdasarkan hal tersebut, menentukan ukuran sampel yang biasa digunakan dalam hitung cepat menurut Melissa, dkk (2002) adalah

$$
n=\frac{z^{2} \cdot[p(1-p)]_{N}}{z^{2} \cdot[p(1-p)]+(N-1) \cdot E^{2}}
$$

dengan

\begin{tabular}{|c|c|c|}
\hline $\mathrm{n}$ & $=$ & jumlah sampel pemilih \\
\hline $\mathrm{Z}$ & $=$ & $\begin{array}{l}\text { mengacu pada tingkat kepercayaan } \\
\text { (untuk } 90 \% \text { adalah } 1,65 \text {, untuk } 95 \%\end{array}$ \\
\hline & & $\begin{array}{l}\text { adalah } 1,96 \text {, untuk } 99 \% \text { adalah } \\
2,58)\end{array}$ \\
\hline $\mathrm{p}(1-\mathrm{p})$ & $=$ & $\begin{array}{l}\text { variasi populasi dalam bentuk } \\
\text { proporsi. Proporsi dibagi dalam dua } \\
\text { bagian dengan total } 100 \% \text { (atau } \\
\mathrm{p}=1 \text { ). Jika populasi diasumsikan } \\
\text { heterogen, maka } \mathrm{p}=0,5\end{array}$ \\
\hline $\mathrm{E}$ & $=$ & $\begin{array}{l}\text { kesalahan sampel yang dikehendaki } \\
\text { (sampling error). Misalnya } 2 \% \text { atau } \\
0,02\end{array}$ \\
\hline N & $=$ & jumlah populasi \\
\hline
\end{tabular}

Berikutnya, dari rumus diatas kita masukkan data nilai pada kasus daerah pemilihan 1 Kabupaten Brebes :

$$
n=\frac{(2,58)^{2} \cdot[0,5(1-0,5)] \cdot 271009}{(2,58)^{2} \cdot[0,5(1-0,5)]+(271009-1) \cdot(0,01)^{2}}=15678
$$

maka jumlah sampel pemilih sebesar 15.678.

\section{PERANCANGAN}

\section{A. Penentuan Sampel TPS Hitung cepat}

Studi kasus pada penelitian ini, menggunakan jumlah sampel pemilih sebanyak 15.678 Jiwa. Jumlah sampel pemilih akan digunakan untuk menghitung jumlah sampel TPS. Jumlah sampel TPS hanya dapat diketahui, jika jumlah sampel pemilih sudah diketahui lebih dahulu.

Kesalahan sampel dan tingkat kepercayaan memiliki hubungan yang saling keterbalikan, semakin besar nilai tingkat kepercayaan maka semakin kecil nilai kesalahan sampel, dan sebaliknya. Dengan melihat hubungan kedua variable tersebut, maka rumus dibawah ini menggambarkan hubungan antara kesalahan sampel dan tingkat kepercayaan :

Kesalahan Sampel $=100 \%-$ Tingkat Kepercayaan
1) Memilih Random 38 TPS dari 660 TPS: Interval sampel diperoleh dengan membagi jumlah total TPS dengan jumlah TPS sampel. Ini berarti, interval sampel adalah 660 dibagi 38 hasilnya 17,37. Dibulatkan menjadi 17. Sampel pertama dipilih dengan melakukan acak (random) angka 1 hingga 19. Sampel ilustrasi pada penelitian ini dimulai dengan nilai 16 . Dengan demikian, angka 16 menjadi sampel awal. TPS dengan urutan nomor 16 menjadi sampel awal hitung cepat.

Sampel pertama dipilih dengan melakukan acak (random) angka 1 hingga 19. Sampel ilustrasi pada penelitian ini dimulai dengan nilai 16 . Dengan demikian, angka 16 menjadi sampel awal. TPS dengan urutan nomor 16 menjadi sampel awal hitung cepat.

Sampel kedua dan seterusnya bisa diperoleh dengan menambah secara sistematis 17. Sampel kedua adalah 33 (hasil dari 16+17), sampel ketiga 50 (hasil dari 33+17), dan seterusnya sehingga ditemukan 38 TPS.

\section{B. Analisa Kebutuhan}

Sistem yang dibuat seringkali tidak sesuai dengan keinginan dari pengguna sistem yang memungkinkan terjadi kesalahan dan ketidaksepahaman. Hal ini biasa terjadi jika dalam pembuatan sebuah sistem tidak diawali dengan analisis kebutuhan yang mendasar dan rinci. Analisis kebutuhan dapat dilakukan melalui wawancara dengan pihak-pihak terkait dan pengamatan dari lingkungan dimana sistem akan dibangun.

1) Kebutuhan Fungsional: Melihat dari tahapan dan disertai keinginan pengguna dalam fitur yang ada dari aplikasi, fungsi yang muncul dikelompokan menjadi :

a) Mengelola user: Merupakan fitur yang berfungsi untuk merubah username dan password untuk mengakses aplikasi hitung cepat.

b) Mengelola data relawan: Merupakan fitur yang berfungsi mengelola data relawan. Menambah, merubah, menghapus dan mengirim pesan singkat kepada relawan.

c) Mengelola data calon: Merupakan fitur yang berfungsi mengelola data calon. Menginput daftar calon dan partai. Data ini nantinya menjadi acuan dalam penentuan urutan calon pada aplikasi hitung cepat.

d) Mengelola data suara: Merupakan fitur untuk mengelola suara hasil hitung cepat. Data sms yang masuk diconvert menjadi data suara untuk masing-masing calon.

e) Mengelola data TPS: Merupakan fitur mengelola informasi TPS dan menyesuaikan data TPS dengan relawan yang bertugas berjaga disana.

f) Mengelola phonebook: Merupakan fitur yang digunakan untuk mengelola kontak nomor telepon. Mengelompokan data kedalah group sesuai dengan fungsinya.

g) Mengelola SMS: Merupakan fitur yang berfungsi mengirim sms, baik per kontak ataupun group.

h) Menampilkan hasil hitung cepat: Merupakan fitur yang menampilkan hasil rekapitulasi hitung cepat akan digambarkan secara grafik.

2) Kebutuhan Dokumentasi: Kebutuhan ini merupakan kebutuhan yang mendukung dari implementasi aplikasi yang akan dibuat. Dokumentasi yang dibutuhkan antara lain :

a) Dokumentasi installasi: Merupakan dokumen yang berisi penjelasan cara installasi aplikasi hitung cepat. 
b) Dokumentasi tutorial: Dokumen yang berisi penjelasan cara penggunaan aplikasi, fungsi dari masingmasing modul, dan mekanisme hitung cepat.

3) Deployment Requirement: Kebutuhan ini merupakan kebutuhan yang mendukung supaya aplikasi dapat diimplementasikan. Dalam penerapannya, dibedakan menjadi dua kategori yaitu :

a) Perangkat lunak: Kebutuhan ini merupakan kebutuhan yang mendukung supaya aplikasi dapat diimplementasikan. Dalam penerapannya, dibedakan menjadi dua kategori yaitu :

1) Sistem operasi: Sistem operasi yang dapat digunakan untuk menjalankan aplikasi berbasis PHP dan MySQL antara lain windows, mac OS, dan Linux asalkan dilengkapi dengan aplikasi web server.

2) Web browser: Aplikasi ini dirancang dalam basis aplikasi web/ localhost oleh karena itu aplikasi web browser sangat diperlukan. Hampir semua web browser dapat digunakan untuk mengakses aplikasi ini seperti Internet Explorer 7 ke atas, Mozilla Firefox, Google Chromer, Safari, dan lainnya.

3) PHP: Aplikasi hitung cepat dijalankan dengan bahasa pemrograman PHP dengan spesifikasi versi PHP 5.3.1.

4) Basisdata: Basisdata yang digunakan sebagai media penyimpanan data dapat menggunakan MySQL 5.1.41.

5) Gammu: Gammu yang digunakan sebagai software pendukung fitur SMS gateway minimal versi 1.32.0.

b) Perangkat keras: Kebutuhan perangkat keras yang digunakan untuk mendukung aplikasi hitung cepat sebagai berikut :

1) Laptop: Merupakan perangkat keras yang menjadi lingkungan di mana aplikasi hitung cepat akan digunakan.

2) Modem: Merupakan perangkat keras digunakan untuk mendukung sistem SMS gateway, dugunakan sebagai alat untuk pengiriman dan menerima SMS. Pada aplikasi hitung cepat menggunakan modem GSM yang didukung oleh gammu.

3) SIM card: Merupakan perangkat keras yang bertindak sebagai operator jaringan pada aplikasi hitung cepat. Cari operator yang menawarkan tarif SMS murah agar dana untuk membeli pulsa bisa ditekan.

\section{IMPLEMENTASI DAN PEMBAHASAN}

\section{A. Implementasi Hitung cepat}

Aplikasi hitung cepat yang telah dibuat memadukan teknik statistika perhitungan hitung cepat dengan teknik manajemen SMS, contoh kasus yang diambil sebagai penelitian adalah pemilihan calon anggota legislatif daerah pemilihan 1 Kabupaten Brebes. Hitung cepat ini dilakukan oleh tim pemenangan calon anggota legislatif nomor urut delapan, Rawuh Gunawan. Diberi nama hitung cepat Tim Rawuh Gunawan (TRG).

1) Menentukan TPS Sampel: Sebelum menentukan jumlah TPS Sampel, aplikasi hitung cepat terlebih dahulu meminta data kondisi daerah pemilihan sebagai input dalam melakukan perhitungan statistika. Gambar 1 menampilkan tampilan halaman input data kondisi daerah pemilihan.

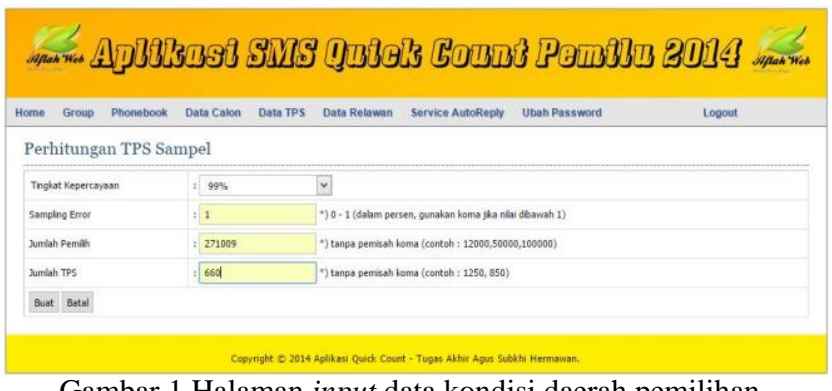

Gambar 1 Halaman input data kondisi daerah pemilihan.

Setelah mengisi data yang diperlukan oleh aplikasi dalam menentukan TPS sampel. Selanjutnya, aplikasi akan secara random memilih TPS sampel. Gambar 2 menampilkan 15 TPS dari 38 TPS sampel yang akan diambil untuk menghitung hasil suara hitung cepat TRG.

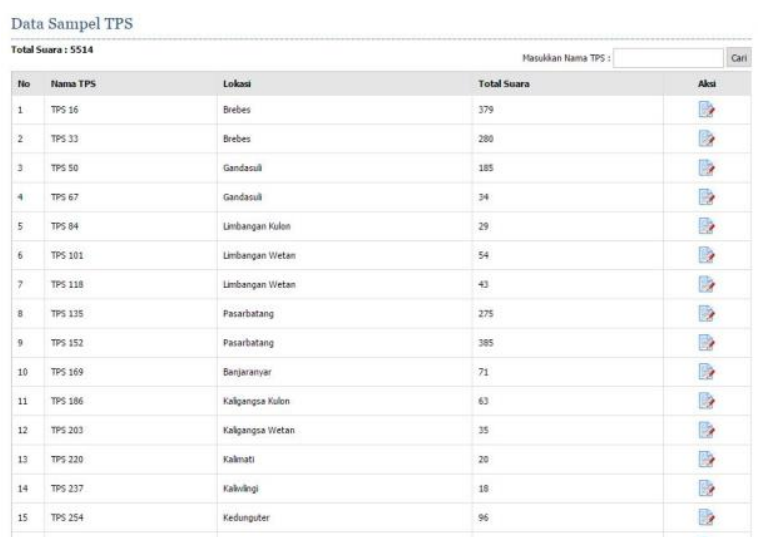

2) Format SMS Hitung cepat TRG: Data penelitian pada kasus ini adalah 3 calon peserta pemilu dari partai gerakan Indonesia raya (Gerindra) di DAPIL 1 Brebes. Berikut ini format SMS hitung cepat TRG:

\section{QC\#NOMOR TPS\#SUARA A\#SUARA B\#SUARA C\#SUARA CALON LAIN}

Keterangan:

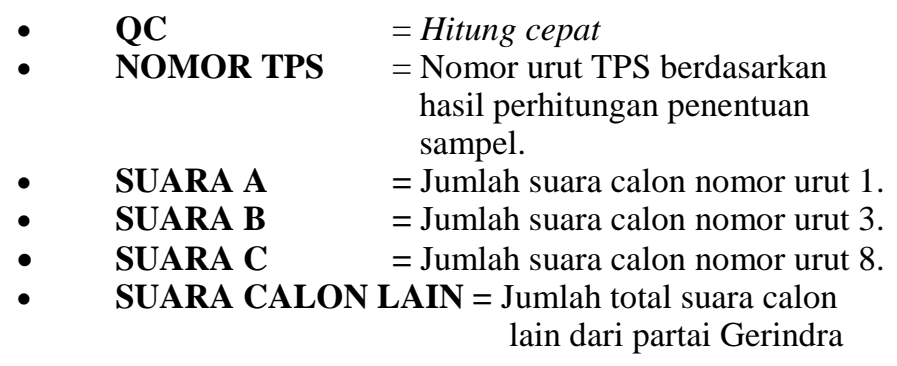

Kami ambil contoh format SMS untuk menghitung suara di TPS 16 Brebes. Format SMS nya :

\section{QC\#TPS 16\#26\#43\#18\#292}

Penjelasan dari format SMS diatas, relawan TPS 16 mengirimkan suara yang diperoleh calon pertama sebesar 26 suara, calon ketiga memperoleh suara sebesar 43 suara, calon nomor urut kedelapan memperoleh suara sebesar 18, dan total suara calon legislatif lain dari partai Gerindra sebesar 292. 


\section{B. Hasil dan Pembahasan}

Data penelitian yang diperoleh dari studi lapangan dan data resmi KPU menjadi acuan kebenaran perolehan suara dari masing-masing calon. Analisa data menjadi penting untuk mengkorelasikan antara perolehan suara hitung cepat TRG dan rekapitulasi KPU, guna mengetahui keberhasilan hitung cepat.

Tingkat ketelitian yang digunakan pada penelitian ini adalah $99 \%$ dengan margin error sebesar 1\%. Oleh karena itu, perolehan suara yang ditunjukan oleh sampel hitung cepat secara keseluruhan harus memiliki nilai kesalahan $<1 \%$ bila dibandingkan dengan hasil rekapitulasi resmi KPU yang dilakukan terhadap seluruh populasi. Bila hal itu memenuhi syarat diatas, maka sampe hitung cepat yang ditentukan untuk mewakili seluruh populasi yang ada dapat dikatakan berhasil. Gambar 3 menampilkan hasil perhitungan suara hitung cepat TRG yang disajikan dalam bentuk diagram oleh aplikasi.

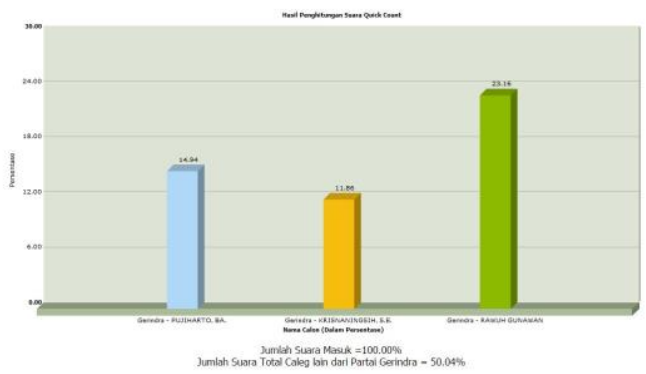

Gambar 3 Hasil perhitungan suara hitung cepat TRG.

Hitung cepat TRG mengambil data perolehan suara dari ketiga calon, antara lain Pujiharto, Krisnaningsih, dan Rawuh Gunawan. Suara calon lain masuk kedalam data 'Jumlah Suara Total Caleg lain dari Partai Gerindra'. Penentuan jumlah calon yang diambil TRG terkait pandangan politik calon mana saja yang berpotensi menjadi pesaing Rawuh Gunawan.

Perolehan suara dari hasil rekapitulasi KPU dan hitung cepat TRG memunculkan calon anggota legislatif nomor urut 8 sebagai calon anggota legislatif yang memperoleh suara terbanyak. Dari hasil rekapitulasi KPU calon anggota legislatif nomor urut 8 memperoleh suara sebesar 2.514 suara dari total 11195 suara keseluruhan partai Gerindra di Dapil 1 Brebes, dengan presentase $22,46 \%$. Sedangkan hasil hitung cepat TRG calon anggota legislatif nomor urut 8 memperoleh suara 1277 suara dari total 5514 suara keseluruhan hitung cepat partai Gerindra, dengan presentase 23,16\%. Tabel 1 menunjukkan perbandingan jumlah perolehan suara hasil rekapitulasi KPU dan hitung cepat TRG yang dilakukan pada penelitian ini.

Tabel 1. Perbandingan Jumlah Suara Hasil Rekapitulasi KPU dan hitung cepat TRG.

\begin{tabular}{|c|c|c|c|c|c|}
\hline \multirow{2}{*}{ Hasil Penelitian } & \multicolumn{3}{|c|}{ Perolehan Suara Caleg } & $\begin{array}{c}\text { Jumlah } \\
\text { Total } \\
\text { Suara } \\
\text { Gerindra }\end{array}$ \\
\cline { 2 - 5 } & $\mathbf{1}$ & $\mathbf{3}$ & $\mathbf{8}$ & \\
\hline \multirow{2}{*}{$\begin{array}{c}\text { Rekapitulasi } \\
\text { KPU }\end{array}$} & Suara & 1743 & 1263 & 2514 & 11195 \\
\cline { 2 - 5 } & Suara & 15,56 & 11,28 & 22,46 & 100 \\
\hline \multirow{2}{*}{\begin{tabular}{c} 
Hitung cepat \\
\cline { 2 - 5 }
\end{tabular}} & 824 & 654 & 1277 & 5514 \\
\hline $\begin{array}{l}\text { Kesalahan / Error Hitung } \\
\text { cepat (\%) }\end{array}$ & 0,62 & 0,58 & 0,70 & 100 \\
\hline
\end{tabular}

Jumlah kesalahan yang terjadi pada hasil perolehan suara hitung cepat terhadap seluruh suara yang masuk adalah sebesar $1,9 \%$ dengan rata-rata kesalahan sebesar $0,63 \%$ disetiap calon anggota legislatif. Kesalahan terbesar terjadi pada perolehan suara calon anggota legislatif urutan 8 sebesar $0,7 \%$ dan kesalahan terkecil terjadi pada perolehan suara calon anggota legislatif urutan 3 sebesar $0,58 \%$. Dengan demikian hasil hitung cepat pada penelitian ini memenuhi margin error yang telah ditentukan yaitu $1 \%$ di tiap perolehan suara calon anggota legislatif.

\section{KESIMPULAN}

\section{A. Kesimpulan}

Penelitian ini menghasilkan aplikasi sistem SMS hitung cepat berbasis PHP dan MySQL dengan metode pengumpulan data suara yang diperoleh dari SMS para relawan di setiap TPS sampel. Hasil dari pengujian aplikasi ini dapat disimpulkan hal-hal berikut.

1. Cara mengolah data dengan menggunakan SMS hitung cepat.

2. Aplikasi ini memiliki tingkat keakuratan data suara hitung cepat sebesar $99 \%$ dengan margin error $1 \%$.

3. Fitus SMS group yang dapat digunakan untuk mengirim SMS ke pemilih.

\section{B. Saran}

Berdasarkan pengujian terhadap aplikasi hitung cepat yang telah dibuat, dapat diberikan beberapa saran sebagai berikut.

1. Aplikasi Hitung cepat ini dapat dikembangkan lebih lanjut dengan menambahkan beberapa fitur yang belum dimasukkan ke dalam aplikasi.

2. Penggunaan yang hati-hati ketika menggunakan fitur penghapusan calon, karena nomor urut calon dalam sistem bisa berubah, lebih baik menggunakan fitur edit calon sehingga tidak akan mempengaruhi hasil hitung cepat yang akan ditampilkan dalam grafik.

\section{DAFTAR PUSTAKA}

[1] Ardiyanti, Handrini, Januari 2013, "Hitung cepat dan Permasalahannya". Info Singkat Pemerintah Dalam Negeri. Volume 5, No. 02, http://berkas.dpr.go.id/pengkajian/files/info_singkat/Info\%20Singkat-V2-II-P3DI-Januari-2013-33.pdf, 9 Maret 2014.

[2] Kasman,A.D. Membangun Aplikasi Sistem SMS Hitung cepat dengan PHP. Kresnamedia. Jawa Barat, 2014.

[3] Rosa, A.S dan M. Shalahuddin. Rekayasa Perangkat Lunak. Informatika Bandung, 2013.

[4] Basuki, Awan Pribadi., Membangun Web Berbasis PHP dengan Framework CodeIgniter., Loko Media., Yogyakarta, 2010.

[5] Hanif, Al Fatta., Analisis \& Perancangan Sistem Informasi. CV. Andi Offset, Yogyakarta, 2007.

[6] A.S, Rosa dan M. Shalahuddin. Modul Pembelajaran Rekayasa Perangkat Lunak. Modula, 2011.

[7] Hirin A.M dan Virgi., Cepat Mahir Pemrograman Web dengan PHP dan MySQL, Prestasi Pustakaraya, Jakarta, 2011.

[8] Adi, A.P dan Sanjay, R. Web Makin Dahsyat dengan JQuery. Kompas Gramedia. Semarang, 2012.

[9] Huda, Miftahul., Komputer, Bunafit., Membuat Aplikasi Database dengan Java, MySQL dan Netbeans. PT. Elex Media Komputindo., Jakarta, 2010.

[10] Solichin, Achmad., Pemrograman Web dengan PHP dan MySQL, Universitas Budi Luhur., Jakarta, 2011.

[11] Santoso ,Harip., Membuat Database pada SQL Server 2000 menggunakan VB 6, PT. Elex Media Komputindo, Jakarta, 2006.

[12] Melissa Estok,dkk. The Hitung cepat and Election Observation. National Democratic Institute for International Affairs. Washington, 2002. 